\title{
History Data Type
}

National Cancer Institute

\section{Source}

National Cancer Institute. History Data Type. NCI Thesaurus. Code C95820.

A data type comprised of a collection of items that are arranged in historical order. 